\title{
WOOD ANATOMY AND CLASSIFICATION OF HENRIQUEZIA SPRUCE, PLATYCARPUM HUMB. ET BONPL. AND GLEASONIA STANDL.
}

\author{
JIFKE KOEK-NOORMAN
}

Instituut voor Systematische Plantkunde, Heidelberglaan 2, 3584 CS Utrecht

\section{SUMMARY}

Wood anatomical generic descriptions of Henriquezia, Platycarpum and Gleasonia are given and compared with data from Rubiaceae. An attempt is made to construct a cladogram according to Hennig's principles. The resulting arrangement of the taxa concerned is discussed and compared with earlier conclusions based on phenetic comparison.

\section{INTRODUCTION}

The taxonomic position of the genera Henriquezia, Platycarpum and Gleasonia has already been subject of several discussions (BREMEKAMP 1952, 1957; CRONQUIST 1968; STEYERMARK 1974). The affinity between Henriquezia and Platycarpum has never been doubted, but no definite solutions have been given of problems like: the relationship of Henriquezia and Platycarpum with Gleasonia or the family to which the three genera should be assigned. Are they rubiaceous or are they more closely related to the complex of Bignoniaceae, Acanthaceae, Pedaliaceae, Martyniaceae, Thunbergiaceae and Mendonciaceae, as suggested by BREMEKAMP (1957)?

At present the problems are tackled again by G. K. Rogers (Arnold Arboretum, Mich), dealing with a familiar treatment of these genera.

In the scope of a short paper on comparative wood anatomy in the Rubiaceae some preliminary remarks were made on the wood of Henriquezia, Platycarpum, and Gleasonia (KOEK-NOORMAN 1977), but wood anatomical descriptions were not given at that time. Furthermore, the conclusions were reached after "phenetic comparison", i. e. looking for similarity, without evaluating the value of the characters in a phylogenetic way. In the present paper the wood anatomy of the genera is described and cladistic methods are employed to compare it with the secondary xylem of Rubiaceae. Other families, mentioned by Bremekamp as near allies were not taken into account. MetCalfe \& ChalK's (1950) family descriptions do not indicate similar wood structures and scanning of the Utrecht slide collections did not reveal new facts.

\section{MATERIALS AND METHODS}

Wood samples were obtained from several institutional wood collections, referred to according to STERN (1978). Herbarium vouchers are listed if known. Sections, 15-25 $\mu \mathrm{m}$ thick were stained with safranin. Macerations, obtained by 
treatment with hydrogen peroxide and glacial acetic acid were stained with astrablue. Vessel member length, vessel diameter and -number, fibre length and - diameter, were averaged out of 25 measurements for each sample. In the generic descriptions lowest and highest averages are given. In measuring ray height the lowest rays were not taken into account. The given values are therefore no true averages but should be considered as indications for frequently occurring ray heights. Ray frequencies are based on 12 counts, each over $1 \mathrm{~mm}$ distance in tangential sections.

\section{GENERIC DESCRIPTIONS}

\section{Gleasonia Standley (figs. 1-3).}

Trees from N.-Brazil and Venezuela; 4 species.

Material studied: G. duidana Standley: Venezuela - Gleason 467 (SJRw16184).

G. uaupensis Ducke: Brazil, Amazonas - Ducke 223 (SJRw 31950).

Growth rings absent.

Vessels diffuse, solitary with only incidentally two pores connected tangentially or radially, round, diameter up to $100-110 \mu \mathrm{m}, 13.6-29.8$ per sq.mm, walls 2-4 $\mu \mathrm{m}$ thick. Vessel member length $1050-1303 \mu \mathrm{m}$, perforations simple in oblique end walls, intervessel pits alternate, oval, vestured, 5-7 $\mu \mathrm{m}$; vesselparenchyma and vessel-ray pits similar to intervessel pits, but half-bordered.

Fibres non-septate, lumen diameter 8-12 $\mu \mathrm{m}$, walls 8-14 $\mu \mathrm{m}$ thick, with frequent, large bordered pits on tangential and radial walls. Length 1205-1609 $\mu \mathrm{m}$.

Rays uniseriate, heterogeneous, the upright cells and procumbent cells differ clearly, and square cells are lacking, up to 8 rows of upright cells alternating with 1-4 rows of procumbent cells, and this repeated several times, up to 28 cells and $2250 \mu \mathrm{m}$ in height, width up to $25 \mu \mathrm{m} ; 8-12$ per $\mathrm{mm}$.

Parenchyma very scanty paratracheal and diffuse, strands of 2-4 cells.

Note: in G. duidana many vessels are filled with coloured, amorphous contents and small tyloses.

\section{Henriquezia Spruce (figs. 4-7).}

Trees from tropical S.-America, 9 species.

Material studied: $\boldsymbol{H}$. jenmani K. Schum.: Br. Guyana - For. Dept. 3583.

H. macrophylla Ducke: Brazil, Rio Curicuriary - Ducke 293.

$H$. verticillata Bth.: Brazil - Ducke 36; Jard. Bot. R. de Janeiro - Ducke s.n.

Growth rings absent.

Vessels diffuse, solitary with only incidentally two pores connected tangentially, round to oval diameter up to $110-225 \mu \mathrm{m}$, walls $3-5 \mu \mathrm{m}$ thick, $4.8-10.6$ per sq.mm. Vessel member length $944-1217 \mu \mathrm{m}$; perforations simple in more or less transverse end walls, intervessel pits alternate, round to oval, vestured, 6-8 $\mu \mathrm{m}$; vessel - parenchyma and vessel-ray pits similar to the intervessel pits, but half-bordered; sclerotic tyloses filling the vessel lumens.

Fibres non-septate, lumen $8-12 \mu \mathrm{m}$, walls $8-15 \mu \mathrm{m}$ thick, with frequent, large 
bordered pits on tangential and radial walls. Length $1365-1632 \mu \mathrm{m}$.

Rays uniseriate, heterogeneous consisting of upright, square and procumbent cells, 2-6 rows of upright or square cells alternating with 1-10 rows of procumbent cells, some parts of procumbent cells over a very short distance biseriate. Up to 45 cells, $2250 \mu \mathrm{m}$ in height, width up to $40 \mu \mathrm{m} ; 8-10$ per mm. Many procumbent and upright cells are sclerotic.

Parenchyma scanty diffuse and in short, 2-3 cells wide bands; paratracheal as narrow vasicentric rings and aliform with short wings, sometimes the wings longer and confluent; many cells sclerotic. Strands of 2-5 cells.

Note: The conspicuous sclerotic ray and parenchyma cells, and sclerotic tyloses as seen in $H$. macrophylla and $H$. verticillata, are lacking in $H$. jenmani and in $H$. verticillata, Ducke s.n.

Both specimens of $H$. verticillata show some rays with biseriate parts of procumbent cells over $2-6$ cells in height.

\section{Platycarpum Humb. \& Bonpl. (fig. 8-9).}

Trees from the Northern part of $\mathrm{S}$. America; 12 species.

Material studied: P. orinocense Humb. \& Bonpl.: Brazil - Ducke 237 (SJRw 31964); Venezuela Maguire, Wurdack \& Keith 42655 (MADw 21746).

P. maguirei Steyermark: Venezuela - Maguire, Wurdack \& Keith 42597 (MADw 23590).

Growth rings absent.

Vessels diffuse, solitary with only incidentally two pores connected tangentially or radially, round or oval, diameter up to $150-200 \mu \mathrm{m}$, walls $3-4 \mu \mathrm{m}$ thick, 3-6 per sq.mm.

Vessel member length $891-1165 \mu \mathrm{m}$, perforations simple in nearly transverse end walls, intervessel pits alternate, oval, vestured, $6-7.5 \mu \mathrm{m}$, vessel-parenchyma and vessel-ray pits similar to intervessel pits, but half-bordered.

Fibres non-septate, lumen diameter $12-16 \mu \mathrm{m}$, walls $6-12 \mu \mathrm{m}$ thick, large bordered pits frequent on tangential and radial walls. Length $1453-1690 \mu \mathrm{m}$.

Rays uniseriate, heterogeneous, up to 20 rows of procumbent cells with 1-3 marginal rows of upright cells, up to 28 cells and $750-1000 \mu \mathrm{m}$ in height, width $25-40 \mu \mathrm{m} ; 9-9.2$ per $\mathrm{mm}$.

Many cells contain small coloured particles.

Parenchyma: paratracheal in narrow, sometimes incomplete, rings with one or two wings, often aliform confluent. Strands of 3-6 cells.

\section{DISCUSSION}

\subsection{The wood anatomy of Gleasonia}

When establishing the genus Gleasonia, STANDLEY (1931) placed it tentatively in the Rondeletieae. SteYermark (1974) agrees with this decision contrary to BREMEKAMP. In the latter's opinion, Gleasonia should be removed from the Rubiaceae into the Tubiflorae (1952). Later, however, he changed his first decision (1957), and accepted Gleasonia in the Rubiaceae, although he considered the genus deviating from all other rubiaceous groups and created a new subfamily Gleasonioideae. 
In my preliminary survey of the wood anatomy of the Rubiaceae $(1969 \mathrm{a}, \mathrm{b})$ Gleasonia was not included because at that time no material was available. In a cluster analysis of a dataset of some tribes of the subfamily Cinchonoideae (KoEK-Noorman \& Hogeweg 1974, Hogeweg \& Koek-Noorman 1975) Gleasonia was included as well as representatives of 8 other genera from the Rondeletieae. As far as Gleasonia is concerned it appeared that, although the analysis did not suggest a definite separation of Gleasonia from the other Rondeletieae, the ambiguities in existing classifications were traced in the iteration: the two represented species were often placed in one cluster with Condamineae and Cinchoneae. This confirms Bremekamp's idea that Gleasonia does not come very close to one special group of Rubiaceae. However, all features characterising Gleasonia occur in other Rubiaceae, in particular within the subfamilies Ixoroideae and Cinchonoideae. For instance:

The presence of fibre tracheids* is typical for most tribes of these subfamilies, solitary vessels and uniseriate heterogeneous rays (though without the pronounced difference between upright and procumbent cells; fig. 2,3) occur in several species of the Gardenieae, Ixoreae, and Cinchoneae. The very scanty diffuse and paratracheal parenchyma is not very common, but the feature occurs incidentally in some genera belonging to the two subfamilies mentioned above.

As no taxonomist (with the exception of Bremekamp, see above) ever suggested to place Gleasonia in another family and as I did not find arguments in the wood anatomy either, I concluded on the base of an overall similarity that the wood anatomical structure of Gleasonia duidana and G. uaupensis confirms a close relationship with rubiaceous tribes from the subfamilies Cinchonoideae and Ixoroideae, without a definite support for a position in any particular tribe.

\subsection{The wood anatomy of Henriquezia and Platycarpum}

SteyermarK (1974), contrary to BremeKamp (1957), considers Henriquezia and Platycarpum as true rubiaceous genera, and places them in a separate tribe in the neighbourhood of Cinchoneae, Rondeletieae and Condamineae. VERDCOURT (1958) follows Bremekamp in the exclusion of the Henriquezieae. When we compare the available wood samples of Henriquezia and Platycarpum we see a very good similarity. Conspicuous corresponding features are the solitary vessels surrounded by paratracheal, often aliform-confluent parenchyma (figs. 4,8 ), the fibre tracheids and the presence of uniseriate heterogeneous rays ( $f$ igs. 5 , $6,9)$. The only difference distinguishing between the two genera seems to be the distribution of the different types of ray cells: in Henriquezia we see up to 10 rows of procumbent cells alternating with 2-6 rows of upright cells, whereas the

\footnotetext{
- The fibres of Henriquezia, Platycarpum, and Gleasonia are typical fibre tracheids, irrespective of whether the definition according to REINDERs (1935) or as formulated in the "Multilingual glossary of terms used in wood anatomy" (1964) is used. Fibre tracheids in the sense of Reinders appeared to have taxonomic value within many groups of the Rubiaceae. Therefore his definition has been accepted in earlier papers (KOEK-NOORMAN 1969a, 1974).
} 
samples of Platycarpum show procumbent cells arranged in up to 20 rows with only few rows of upright marginal cells. Furthermore, the distinct difference between upright and procumbent cells, found in Henriquezia, is in Platycarpum more or less undone by the lower upright cells and the presence of relatively more square cells. The sclerotic cells occurring in the rays and the axial parenchyma of samples of $H$. marginata and $H$. verticillata (fig. 7) have not been found in the other samples of this genus and are therefore not useful in distinguishing between the two genera.

Comparing the wood of Henriquezia and Platycarpus with the two samples of Gleasonia, we see a good agreement, the only conspicuous difference being found in the parenchyma pattern: in Gleasonia the parenchyma is very scanty in diffuse and paratracheal strands (fig. I), in Henriquezia and Platycarpum the paratracheal parenchyma occurs in aliform-confluent arrangement. Contrary to the other features, which, as already mentioned in paragraph 4.1. occur more or less frequently within the Rubiaceae, aliform-confluent parenchyma is unknown for this family.

In an earlier paper (KOEK-NOORMAN 1977) I used a "phenetic" approach in the discussion of the position of the three genera concerned. The difference in parenchyma arrangement was my main argument to endorse Bremekamps creation of a new family Henriqueziaceae. Besides, I mentioned some additional features. The most conspicuous one, the pronounced differentiation in procumbent and upright cells in the exclusively unseriate rays is unusual within the Rubiaceae.

\subsection{Cladistic approach}

If cladistic principles (in the sense of HENNIG 1966; for an earlier application of cladistics in wood anatomy see BAAS \& ZWEYPFENNING 1979) are applied on the wood anatomical data in order elucidate the taxonomic relationship between "Henriqueziaceae" and Rubiaceae, the first assumption must be, that Henriquezia, Platycarpum and Gleasonia are "more related" to the Rubiaceae than to any other family (as f.i. one of the Tubiflorae; BREMEKAMP 1957). As said before, I found no striking agreement with any of the families mentioned. Therefore I feel justified to exclude the Tubiflorae from the following considerations.

Some of the features Henriquezia, Platycarpum and Gleasonia have in common, are considered to be "primitive" according to the "evolutionary trends" as established for wood anatomical features. These characters are the presence of fibre tracheids, the exclusively solitary, diffusely arranged vessels, the heterocellular rays (BAILEY \& TUPPER 1918; Frost 1930; KRIBS 1935). Each of these characters occurs in many representatives of the Rubiaceae (KOEK-NOORMAN 1969a, b, 1970, 1972; KoEK-NoORMAN \& HogewEg 1974). The most conspicuous deviating character found in Henriquezia and Platycarpum is the aliform-confluent parenchyma. This distribution pattern has not been found elsewhere in the Rubiaceae. The common patterns in this family are : apotracheal as diffuse or reticulate strands and paratracheal as scanty strands, or absence of parenchyma. As pointed out by BREMER \& WANNTORP (1978) the fact that a 

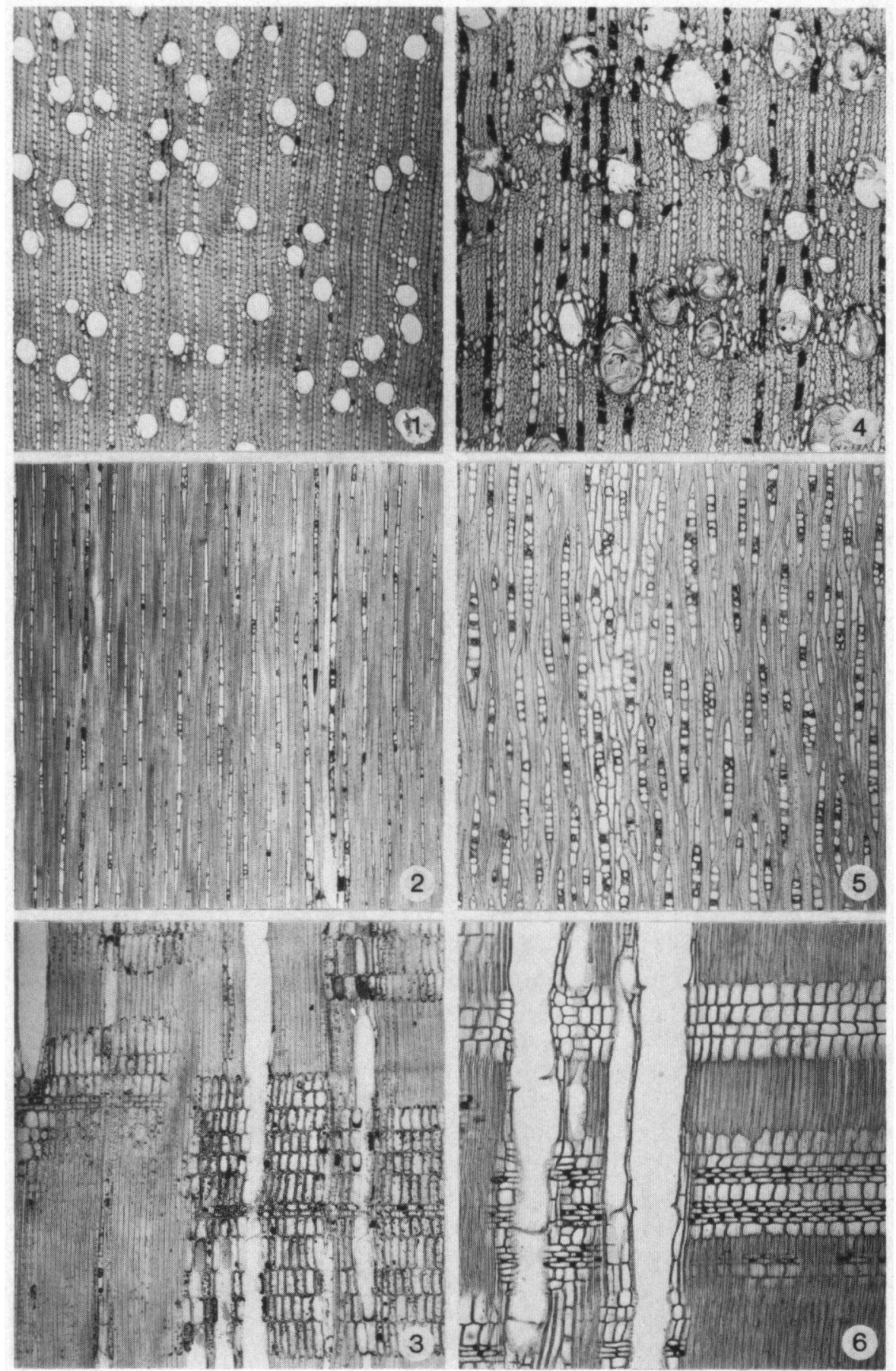

Plate I. 

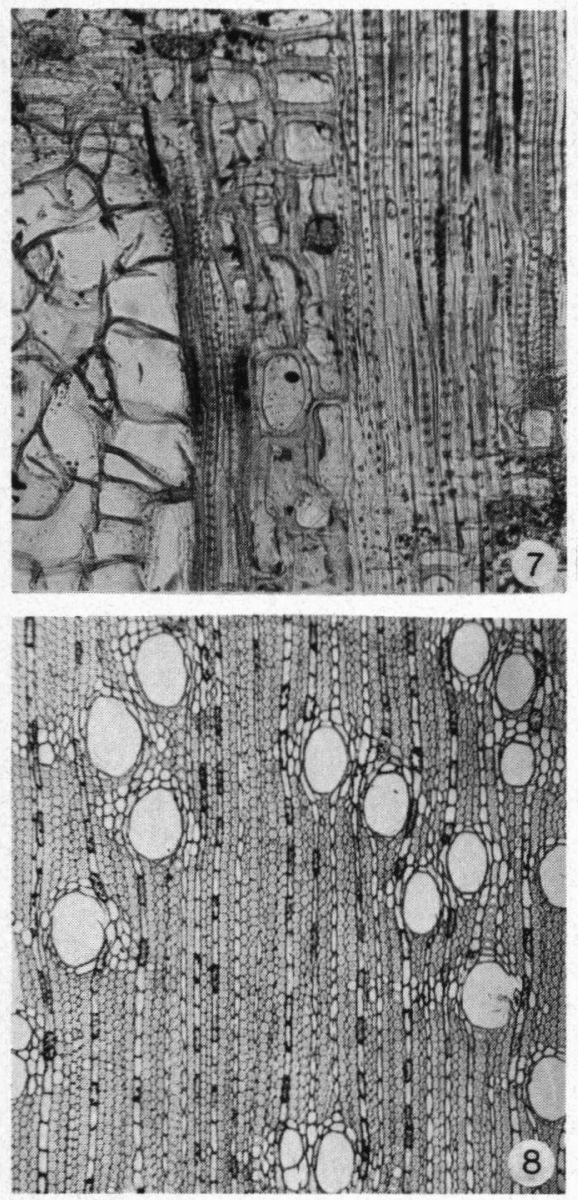

Plate II.

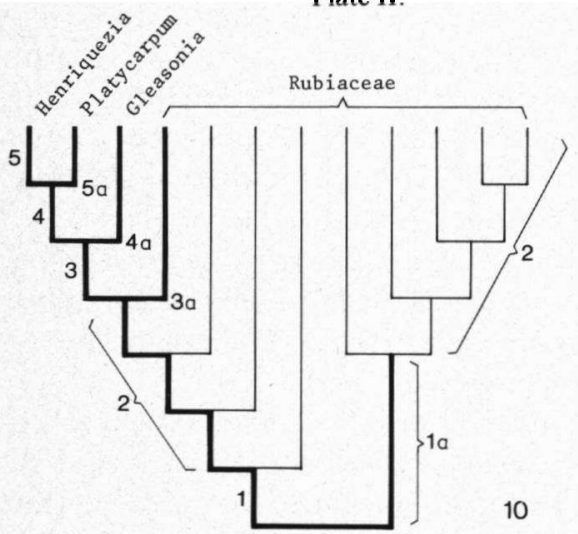

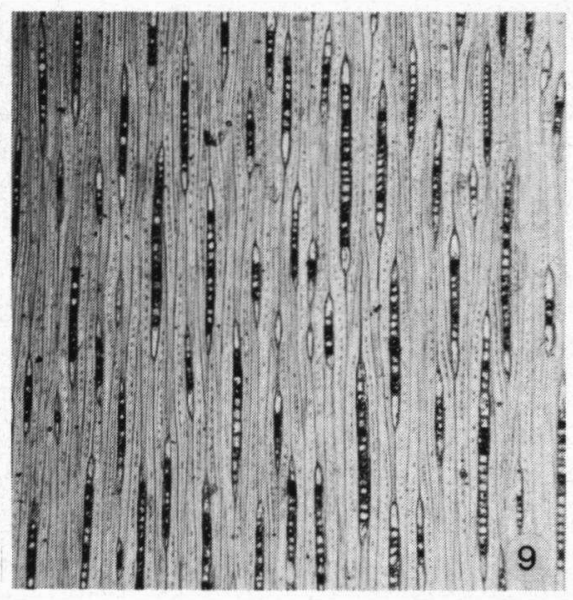

Plate I.

Fig. 1. Gleasonia uaupensis Ducke (Ducke 223), transverse section, $\times 40$.

Fig. 2. Do, tangential section, $\times \mathbf{4 0}$.

Fig. 3. Do, radial section, $\times 40$.

Fig. 4. Henriquezia macrophylla Ducke(Ducke 293), transverse section, $\times 40$.

Fig. 5. H. verticillata Bth. (Ducke 36), tangential section, $\times 40$.

Fig. 6. H. jenmani K. Schum. (Br. Guy. For. Dept. 3583) radial section, $\times 40$.

\section{Plate II.}

Fig. 7. $H$. verticillata Bth. (Ducke 36), radial section, showing sclerotic cells in axial and radial parenchyma, $\times 100$.

Fig. 8. Platycarpum orinocense Humb. \& Bonpl. (Maguire, Wurdack \& Keith 42655), transverse section, $\times \mathbf{4 0}$.

Fig. 9. Do (Ducke 237), tangential section, $\times 40$.

Fig. 10. Cladogram representing possible phylogenetic relationships as deduced from wood anatomical features:

1-1a: bifurcation representing differentiation in fibre-tracheids (1) and libriform fibres (1a). 2: bifurcation representing successive differentiation of several wood anatomical features in Rubiaceae. Thin lines indicate that in the text no attention has been paid to the meaning of these lines.

3-3a: bifurcation representing uniseriate heterogeneous rays (3) and multiseriate rays (3a). 4-4a: bifurcation representing aliformconfluent (4) and scanty paratracheal parenchyma (4a).

5-5a: bifurcation representing the tendency from heterogeneous uniseriate (5) to homogeneous uniseriate rays (5a). 
character occurs in one relatively small group can be strong evidence in favour of the idea, that the character is the derived, apomorphous state. The conclusion, that aliform-confluent parenchyma is an apomorphous character-state is in accordance with the literature on evolutionary trends (KRIBS 1937; CARLQUIST 1961). In a diagram representing possible phylogenetic sequences it may be used therefore, to separate Henriquezia and Platycarpum from a "sister group", to be found among the other Rubiaceae.

The number of Rubiaceae with the features mentioned for Henriquezia and Platycarpum, with the sole exception of aliform-confluent parenchyma, is restricted. Even among the tribe Gardenieae and Ixoreae for which tribes all mentioned features have been recorded, uniseriate heterogeneous rays are rare especially with a pronounced difference in procumbent and upright ray cells, as seen in Henriquezia. The samples of Gleasonia, however, have all requirements of a sister group. A satisfactory cladogram is thus obtained, if Henriquezia and Platycarpum are combined in one larger unit with Gleasonia (fig. 10).

To indicate the difference in ray structure in Platycarpum a very last bifurcation may represent the trend from heterogeneous to more homogeneous ray structure. More or less homogeneous uniseriate rays occur in species of several rubiaceous tribes which otherwise show many multiseriate heterogeneous rays. Following the cladistic method we may assume that the character of exclusively uniseriate rays has been developed more than once within the Rubiaceae, but that Henriquezia, Platycarpum and Gleasonia are monophyletic in this respect. Recently a comparable consideration concerning the rays of Lythraceae has been put forward by BAAS \& ZWEIPFENNING (1979). It seems impossible to elaborate a further detailed phyletic diagram for the Rubiaceae. The range of variation of the other wood anatomical features is so narrow that it makes no sense to give them evolutionary or phyletic value. The only exception can perhaps be found in the fibre types. Both fibre tracheids and libriform fibres occur within the Rubiaceae. At least in some tribes of the Ixoroideae and Cinchonoideae a significant correlation with other wood anatomical features has been found (KoEK-NoORMAN \& HoGEWEG 1974). Furthermore, there is a correlation between these sets of characters and existing taxonomic classifications. On account of these two facts I assume that the differentiation of the fibre types has taken place in a relative early phase of development of the Rubiaceae. This is indicated by a first bifurcation in the cladogram (fig. 10). Henriquezia, Platycarpum and Gleasonia should be placed high up in the branch representing the Rubiaceae with fibre tracheids. Between this basal bifurcation and the "thin twigs" at the upper side of the diagram, we must imagine a number of bifurcations, representing subsequent differentiations; often along comparable lines in the left and right half of the diagram.

Irrespective of how the intermediate part of the diagram should be worked out, the group of Henriquezia and Platycarpum, as well as Gleasonia, will be placed on the same hierarchic level as other parts of the family Rubiaceae as far as I can judge.

On the line of reasoning of HENNIG (1966), repeated by BREMER \& W ANNTORP 
(1978), it is not possible to support the family rank for Henriquezia and Platycarpum (with or without Gleasonia) while all other Rubiaceae are maintained in one large family. The correct solution should be: either to maintain Henriquezia and Platycarpum as well as Gleasonia in the Rubiaceae, or to split up the Rubiaceae in a large number of small families, among them the "Henriqueziaceae" and "Gleasoniaceae". As the Rubiaceae have always been considered as a "natural", well defined family, the splitting up in small families will probably find no supporters.

I am aware of some incompleteness in the data. The number of studied samples is relatively low, and the wood anatomy of other related families should be included in the discussion, to allow a more definite answer. Furthermore a more elaborated diagram, worked out from the top to the basal side could be more convincing. Nevertheless I feel that in this phase the following conclusions are justified.

1. A comparison of the wood anatomy of Gleasonia with that of Henriquezia and Platycarpum and with Rubiaceae in general confirms an earlier conclusion (1977), that Gleasonia is more similar to Rubiaceae than are Henriquezia and Platycarpum.

2. If those taxonomists, who consider Henriquezia, Platycarpum and Gleasonia nearly allied to the Rubiaceae are right, the nearest relatives are to be sought among representatives of the subfamilies Ixoroideae or Cinchonoideae.

3. An analysis along cladistic lines does not endorse a division in two families Rubiaceae and Henriqueziaceae (including Henriquezia and Platycarpum, with or without Gleasonia). This is contrary to the conclusion based on phenetic comparison (KoEK-NOORMAN 1977).

4. If Henriquezia and Platycarpum are removed from the Rubiaceae, according

to cladists the remaining family should be considered as a phenetic unity, rather than as a phyletic unity.

The two last formulated points start from the principle, that the cladistic analysis of characters not only precedes a (taxonomic) classification, but that the cladogram in itself represents the correct classification of the studied objects. As MAYR (1974) has argued, there is no reason to assume that cladistic analysis and cladistic classification should be inseparably combined. There may be several reasons to abandon the idea of equal taxonomic ranks for sister groups, or to bring together polyphyletic (in the cladistic sense) groups in a taxon of equal rank as a small "sideline" (see also BURGER 1979). For the time being, to uncouple analysis and classification seems to be the best thing to do. Although in the cladogram the three genera are separated from a rubiaceous sister group on a high level, they are easily to distinguish from the other Rubiaceae because of the parenchyma pattern and the ray structure. Inclusion of, above all, Henriquezia and Platycarpum makes the wood structure of Rubiaceae more diverse. However, if the decision should be to keep Henriquezia and Platycarpum apart, the cladogram indicates that the wood anatomy of Gleasonia would justify inclusion in the "Henriqueziaceae" as much as maintenance in the Rubiaceae. It will be clear that the wood anatomy will not give the last word on this taxonomic 
problem. Careful analyses of data from other plant parts are essential, before a definite solution can be given.

\section{REFERENCES}

BAAs, P. \& R. C. V. J. ZWEYPFENNING (1979): Wood anatomy of the Lythraceae. Acta Bot. Neerl. 28: $117-155$.

BaILeY, I. W. \& W. W. TUPPER (1918): Size variation in tracheary cells. I. A comparison between the secondary xylems of vascular Cryptogams, Gymnosperms, and Angiosperms. Pro. Amer. Sci. 54: 149-204.

BremeKAMP, C. E. B. (1952): The African species of Oldenlandis L. sensu Hiern. \& K. Schum. Verh. Kon. Ned. Ak. 2e ser. 48(2): 27.

- (1957): On the position of Platycarpum Humb. \& Bonpl., Henriquezia Spr. ex Bth., and Gleasonia Standl. Acta Bot. Neerl. 6: 351-357.

Bremer, K. \& H. Wanntorp (1978): Phylogenetic systematics in Botany. Taxon 27: 317-329.

BURGER, W. C. (1979): Cladistics: useful tool or rigid dogma? Taxon 28 : 385-386.

Carlquist, S. (1961): Comparative Plant Anatomy. New York: Holt, Rinehart \& Winston.

CRONQUIST, A. (1968): The evolution and classification of flowering plants. Boston, Houghton Mifflin Cy.

Frost, F. H. (1930): Specialization in secondary xylem of dicotyledons. I. Origin of vessel. Bot. Gaz. $89: 67-94$.

Hennig, W. (1966): Phylogenetic systematics. Urbana, Univ. of Illinois Press.

HoGEWEG, P. \& J. KOEK-NOORMAN (1975): Wood anatomical classification using iterative character weighing. Acta Bot. Neerl. 24 : 269-283.

International Association of Wood Anatomists (1964): Multilingual glossary of terms used in wood anatomy. Winthertur.

KOEK-NOORMAN, J. (1969a): A contribution to the wood anatomy of South American (chiefly Suriname) Rubiaceae. I. Acta Bot. Neerl. 18 : $108-123$.

- (1969b): A contribution to the wood anatomy of South American (chiefly Suriname) Rubiaceae. II. Acta Bot. Neerl. 18 : 377-395.

- (1970): A contribution to the wood anatomy of the Cinchoneae, Coptosapelteae, and Naucleeae (Rubiaceae). Acta Bot. Neerl. 19: 145-164.

- (1972): The wood anatomy of Gardenieae, Ixoreae, and Mussaendeae (Rubiaceae). Acta Bot. Neerl. 21 : 301-320.

- (1977): Systematische Holzanatomie einiger Rubiaceen. Ber. Deutsch. Bot. Ges. 90: 183-190.

- \& P. Hogeweg (1974): The wood anatomy of Vanguerieae, Cinchoneae, Condamineae, and Rondeletieae (Rubiaceae). Acta Bot. Neerl. 23 : 627-653.

KRIBS, D. A. (1935): Salient lines of structural specialization in the wood rays of Dicotyledons. Bot. Gaz. 96: 547-557.

- (1937): Salient lines of structural specialization in the wood parenchyma of Dicotyledons. Bull. Torr. Bot. Club 64: 117-175.

MAYR, E. (1974): Cladistic analysis or cladistic information? Z. Zool. Syst. Evol. - Forsch. 12: 94-128.

Metcalfe, C. R. \& L. Chalk (1950): Anatomy of the Dicotyledons, Oxford, Clarendon Press.

REINDERs, E. (1935): Fiber-tracheids, libriform fibers and systematics in wood anatomy. Trop. woods 44: $30-36$.

Standley, P. C. (1931): The Rubiaceae of Bolivia. Field Mus. Nat. Hist. Bot. ser. $9: 253-340$.

STERN, W. (1978): Index Xylariorum. Institutional Wood collections of the world. 2. Taxon 27: 233-269.

SteYermark, J. A. (1974): Flora de Venezuela. IX. 1. Caracas; Inst. Bot. Ed.

Verdcourt, PH. D. (1958): Remarks on the classification of the Rubiaceae. Bull. J. Bot. Brux. 28: 209-290. 